\title{
WIZYTACJE KANONICZNE I DZIEKAŃSKIE W ARCHIDIECEZJI LWOWSKIEJ OBRZĄDKU LACIŃSKIEGO DO 1939 ROKU
}

\section{Wstęp}

Wizytacje kanoniczne biskupów (visitatio canonica, visitatio pastoralis), w powierzonych im diecezjach, miały na celu poznanie stanu oraz potrzeb parafii i zaradzenie im przez władzę kościelną. O tym obowiązku rządcom diecezji przypomniał m.in. Sobór Trydencki (1545-1563), który też polecał sufraganom (biskupom pomocniczym) pomagać im w tym względzie. Zobowiązywał także dziekanów do odbywania regularnych wizytacji w parafiach swoich dekanatów oraz informowania biskupów o ich stanie'.

Normy dotyczące wizytacji kanonicznych parafii w XX w. podawał Kodeks Prawa Kanonicznego z 1917 roku, który mówił m.in., że biskup „rezydencjonalny" powinien każdego roku wizytować swoją diecezję lub jej część tak, aby przynajmniej raz na pięć lat nawiedzić każdą parafię. To zadanie miał wypełniać osobiście lub - w razie uzasadnionej przeszkody - przez wikariusza generalnego albo przez innego duchownego. Wizytacji podlegały wszystkie osoby i rzeczy oraz „zakłady pobożne”, za wyjątkiem tych, które otrzymały od Stolicy Apostolskiej specjalną egzempcję. Gdyby biskup zaniedbywał wizytacje kanoniczne w swej diecezji, to wówczas metropolita miał powiadomić o tym Stolicę Apostolską, która obligowała biskupa do zadośćuczynienia ciążącemu na nim obowiązkowi².

* Bp Mariusz Leszczyński - dr historii Kościoła, biskup pomocniczy diecezji zamojsko-lubaczowskiej.

${ }^{1}$ A. F., Wizytacja kościelna, w: Podręczna Encyklopedia Kościelna, t. 41-42, Warszawa 1915, s. 349.

${ }^{2}$ Codex Iuris Canonici (CIC) z 1917 roku, Watykan 1943, kan. 343 §1 i 3, 344 §1 i 2, 345, 346; F. Bączkowicz, Prawo kanoniczne. Podręcznik dla duchowieństwa, t. 1, Opole 1957, s. 515-517. 


\section{Akta wizytacyjne $w$ archiwum archidiecezjalnym}

Inwentarz Archiwum Archidiecezjalnego ob. łac. we Lwowie, opracowany rzez Stanisława Zajączkowskiego w latach 1930-193133, wymienia 14 jednostek archiwalnych (księgi i fascykuły, bez ich opisu), zawierających akta wizytacyjne z lat 1712-1857. Są to sprawozdania z wizytacji arcybiskupów: Jana Skarbka (1712-1733) z lat 1716-1725 i Mikołaja Ignacego Wyżyckiego (1737-1757) z 1741 roku, biskupa bakowskiego i sufragana lwowskiego Stanisława Rajmunda Jezierskiego (1734-1782) z lat 1754-1755, arcybiskupów: Wacława Hieronima Sierakowskiego (1760-1780) z lat 1771-1780 (2 fasc.), Kajetana Ignacego Kickiego (1797-1812) z lat 1796 i 1800, Andrzeja Alojzego Ankwicza (1814-1833) z lat 1817-1833 (6 fasc.), Franciszka de Paula Piszteka (1836-1846) z lat 1836-1844 i Łukasza Baranieckiego (1849-1858) z lat 1850-18574. Już z tego zestawienia widać, że w archiwum archidiecezjalnym nie ma najstarszych akt wizytacyjnych, gdyż prawie wszystkie, poza kilkoma sprawozdaniami w formie szczątkowej, podobnie jak i inne archiwalia, przechowywane dawniej zapewne w rezydencji arcybiskupów w Obroszynie, uległy zniszczeniu na skutek wojen i pożarów ${ }^{5}$. Natomiast te sprawozdania, które się zachowały, stanowią ważny materiał źródłowy do poznania życia religijnego oraz stanu duchowieństwa i parafii archidiecezji ${ }^{6}$. Dokładny opis tych sprawozdań zamieścił ks. Janusz Kania, b. pracownik Ośrodka „Archiwa, Biblioteki i Muzea Kościelne”, w zrekonstruowanym przez siebie schemacie archiwum archidiecezji lwowskiej, w połowie lat 80. XX w. ${ }^{7}$ Okazuje się, że np. fascykuł nr 12 zawiera także wizytacje biskupów chełmskich: Jana Feliksa Szaniawskiego (1725-1733), Józefa Eustachego Szembeka (1736-1753), Walentego Wężyka (1752-1765) i Antoniego Onufrego Okęckiego (1770-1775), przeprowadzone w latach 1726-1772 w dekanacie Bełz ${ }^{8}$, utworzonym i włączonym do archidiecezji lwowskiej w $1787 \mathrm{roku}^{9}$.

Wymienione przez S. Zajączkowskiego i ks. J. Kanię akta wizytacyjne nie odpowiadają jednak aktualnemu stanowi zawartości tegoż działu archiwum archidiecezji, które obecnie jest przechowywane w Krakowie ${ }^{10}$. Już bowiem przed II wojną światową ks. Stanisław Szurek, który badał zasoby tegoż archiwum, stwierdził, że „są tam sprawozdania także z innych wizytacji, ale przedstawiają materiał

${ }^{3}$ Inwentarz Archiwum Archidiecezjalnego ob. łac. we Lwowie, sporządził S. Zajączkowski w latach 1930-1931, Lwów 1931, ss. 203 [mps, kopia w zbiorach autora].

${ }^{4}$ Tamże, s. 56.

${ }^{5}$ S. Zajączkowski, Archiwum Archidiecezjalne ob. łac. we Lwowie, Lwów 1932, s. 5.

${ }^{6}$ Tamże, s. 9-10.

${ }^{7}$ J. Kania, Katalog mikrofilmów Ośrodka Archiwów, Bibliotek i Muzeów Kościelnych przy Katolickim Uniwersytecie Lubelskim, nr 5, oprac. J. Kania, ABMK, 51 (1985) s. 8-104; cyt. za nadb., Lublin 1985, s. 3-100.

${ }^{8}$ Tamże, s. 51-54.

${ }^{9}$ B. Kumor, Granice metropolii i diecezji polskich (966-1939) - nadb. „Archiwa, Biblioteki i Muzea Kościelne”, 18-23 (1969-1971) s. 277-283.

${ }^{10}$ „Archiwum abpa E. Baziaka” w Krakowie, ul. Kanonicza 13. 
znacznie uboższy i zachowany przeważnie w sposób fragmentaryczny"11. Trudno jednak powiedzieć, jakie to były wizytacje, gdyż ks. Szurek ich nie wymienia. Gdy pod koniec lat 70. XX w., z inicjatywy administratora apostolskiego w Lubaczowie bp. Mariana Rechowicza (1910-1983), zaczęto porządkować złożone tam archiwa archidiecezji lwowskiej, okazało się, że akt wizytacyjnych jest znacznie więcej, niż podawały to dotychczasowe ich rejestry. Ich bowiem spis, sporządzony przez pracownika archiwum ks. Stefana Weretczuka, w latach 1980-1983, odnotowuje 60 jednostek archiwalnych (fascykuły i teczki). Są wśród nich m.in. sprawozdania z wizytacji kanonicznych abp. Franciszka Wierzchlejskiego (18601884), nie odnotowane w „Inwentarzu” S. Zajączkowskiego ${ }^{12}$ i dziekańskich od XVII do XX w., a także relacja z wizytacji par. Czerwonogród (diec. kamieniecka), którą przeprowadził bp Sierakowski w 1741 roku $^{13}$.

\section{Wizytacje kanoniczne $w$ archidiecezji w epoce przedrozbiorowej}

W epoce przedrozbiorowej rządcy archidiecezji odbywali wizytacje kanoniczne osobiście lub przez swoich delegatów, zgodnie z zaakceptowanym przez siebie formularzem wizytacyjnym. Nie wszystkie jednak wizytacje były przeprowadzone dokładnie. Świadczą o tym niektóre bardzo skromne protokoły, pochodzące często z drugiej ręki, co miało miejsce wtedy, gdy do danej parafii wizytator nie dotarł osobiście ${ }^{14}$.

Najstarsze wzmianki o wizytacjach kanonicznych archidiecezji lwowskiej pochodzą z 1597 roku, tj. z czasów rządów abp. Jana Dymitra Solikowskiego (15831603). W XVII w. nie odbywały się one regularnie, głównie z powodu częstych wojen. W 1600 roku abp Solikowski wizytował katedrę osobiście, ale już w innych parafiach archidiecezji zastępował go w tym archidiakon Hieronim Solikowski. Podobnie abp Jan Andrzej Próchnicki (1614-1633) do wizytacji parafii delegował archidiakona Jana Baranowskiego, zaś abp Stanisław Grochowski (1633-1645) upoważnił w 1641 roku do wizytowania parafii dekanatu lwowskiego prepozyta żółkiewskiego ${ }^{15}$. Z kolei abp Mikołaj Krosnowski (1645-1653) wizytował w 1647 roku katedrę i kapitułę osobiście, ale nie mógł już kontynuować tej czynności w innych parafiach, ze względu na najazd Tatarów. Stało się to możliwe dopiero za rządów abp. Jana Tarnowskiego (1654-1669), w latach 1661-

${ }^{11}$ S. Szurek, Archiwa archidiecezji lwowskiej ob. łac., Lwów 1934, s. 5 - nadb. „Collectanea Theologica", t. 15, 1934, fasc. 3, s. 367-374.

${ }^{12}$ Archiwum Archidiecezji Lwowskiej w Krakowie („Archiwum abpa E. Baziaka”), t., b. sygn. [Spis zasobów archiwum archidiecezji lwowskiej sporządzony przez ks. Stefana Weretczuka], „Akta wizytacyjne", rkps, ss. 4; M. Leszczyński, Archiwum Archidiecezji w Lubaczowie, ABMK, 53 (1986) [druk 1987], s. 63.

${ }^{13}$ Tamże, s. 3; Kania, Katalog mikrofilmów, s. 95.

${ }^{14}$ J. Krętosz, Organizacja archidiecezji lwowskiej obrządku tacińskiego od XV wieku do 1772 roku, Lublin 1986, s. 62.

${ }^{15}$ Tamże, s. 62-64; M. Gębarowicz, Jan Andrzej Pruchnicki (1553-1633). Mecenas i bibliofil. Szkic z dziejów kultury w epoce kontrreformacji, Kraków 1981, s. 65. 
1662, kiedy to parafie wizytował biskup pomocniczy i oficjał generalny Stefan Charbicki (1657-1663) oraz archidiakon Adam Piastowski, który też w 1678 roku przeprowadzał wizytacje $\mathrm{w}$ archidiecezji jako jej administrator sede vacante ${ }^{16}$.

Podobnie wyglądały wizytacje kanoniczne w archidiecezji w XVIII w. I tak np. abp Konstanty Józef Zieliński (1700-1709) zapowiedział wizytacje, ale nie ma informacji, czy je wykonał. Wiadomo natomiast, że odbyły się one za rządów abp. J. Skarbka (1712-1733). Prowadzili je wówczas, w jego zastępstwie, w dekanacie Halicz i Trembowla: kanonik kamieniecki ks. Franciszek Borzym i dziekan trembowelski ks. Aleksander Józef Młodkiewicz. Łącznie zwizytowali 107 parafii, a ich wyniki arcybiskup przedstawił w 1731 roku w swojej relacji do Rzymu. Jego następca, abp M. Wyżycki (1737-1757) zwizytował w 1741 roku 71 parafii ${ }^{17}$. Z kolei abp W. H. Sierakowski, w okresie swych rządów (1760-1780), zwizytował 133 parafie, konsekrując 27 kościołów. W ich trakcie zwracał szczególną uwagę na stan kościołów, szkół i szpitali, a zebrane spostrzeżenia i wnioski stały się dla niego inspiracją do gruntownych reform $\mathrm{w}$ archidiecezji ${ }^{18}$.

\section{Wizytacje kanoniczne w okresie niewoli narodowej i w dwudziestoleciu międzywojennym}

Już w 1772 roku władze austriackie usiłowały narzucić abp. Sierakowskiemu komisarza rządowego, by towarzyszył mu przy wizytacjach kanonicznych. Ten postulat Tajna Kancelaria przedstawiła, 24 grudnia tr., cesarzowej Marii Teresie, która jednak go nie zatwierdziła, ze względu na sprzeciw arcybiskupa. Arcybiskup, broniąc się przed ingerencją władzy świeckiej w jego czynności pasterskie, argumentował, że dotyczą one wyłącznie spraw wiary, życia religijnego wiernych i kwestii duszpasterskich, a nie działalności politycznej. Nie ma więc podstaw ku temu, by były przedmiotem zainteresowania państwa. Władzom zaborczym udało się tylko, 21 kwietnia 1774 roku, zobowiązać kurię metropolitalną do informowania ich o planowanych wizytacjach kanonicznych, o czym przypominały, co pewien czas, dekrety cesarskie i gubernialne ${ }^{19}$. I taki stan trwał do początku XIX w. Dopiero dekret nadworny, z 12 kwietnia 1810 roku, nakazał obecność urzędnika państwowego i przedstawiciela patrona wizytowanego kościoła przy arcybiskupie wizytującym parafię. Dlatego to np. pod dekretem wizytacyjnym dekanatu buskiego z 1821 roku widnieje adnotacja: Ex parte Domini, ex parte Maiestatis Regia Stefan Jurowicz ${ }^{20}$.

Po 1780 roku, zapewne także na skutek trudności czynionych przez władze zaborcze, wizytacje kanoniczne w archidiecezji nie odbywały się regularnie. I tak np. w okresie rządów abp. Ferdynanda Kickiego (1780-1797) miało miejsce jedy-

\footnotetext{
${ }^{16}$ Krętosz, Organizacja archidiecezji, s. 62, 64, 100.

${ }^{17}$ Kania, Katalog mikrofilmów, s. 48-49; Krętosz, Organizacja archidiecezji, s. 62-64.

${ }^{18}$ Kania, Katalog mikrofilmów, s. 49; Krętosz, Organizacja archidiecezji, s. 64, 67.

${ }^{19} \mathrm{~J}$. Krętosz, Archidiecezja lwowska obrządku łacińskiego w okresie józefinizmu (1772-1815), Lublin 1996, s. 65-66.

${ }^{20}$ Tamże, s. 66-67.
} 
nie 8 wizytacji ${ }^{21}$. Częściej przeprowadzali je, o czym już wspomniano, arcybiskupi: A. A. Ankwicz i F. de Paula Pisztek ${ }^{22}$. Natomiast prawie całą archidiecezję zwizytował abp Łukasz Baraniecki (1849-1858). Nie zdołał tylko dotrzeć do par. Żółtańce i Kukizów, gdyż zmarł, 30 czerwca 1858 roku, w czasie wizytacji par. Cieszanów, gdzie też na tamtejszym cmentarzu spoczęło jego serce ${ }^{23}$. Warto dodać, że ten arcybiskup w czasie wizytacji zbierał odpowiednie materiały do planowanej przez siebie regulacji parafii ${ }^{24}$. Trudno natomiast powiedzieć, dlaczego wizytacji kanonicznych nie prowadził osobiście abp Seweryn Tytus Morawski (1885-1900)?25 Wydał jednak „Instrukcję dla Wielebnych XX. Dziekanów i proboszczów lwowskiej archidiecezji ob. łac. o wizycie kanonicznej” (Lwów 1888), w której wiele miejsca poświęcił m.in. przygotowaniu młodzieży do sakramentu bierzmowania $^{26}$.

Regularne wizytacje kanoniczne parafii prowadził natomiast następca abp. Morawskiego, abp Józef Bilczewski, który w okresie swoich rządów (1900-1923) zwizytował, wraz z biskupem pomocniczym, całą archidiecezję, a niektóre dekanaty nawet dwukrotnie. W ich trakcie nawiedzał kościoły parafialne, filialne i kaplice, szkoły, ochronki i inne instytucje, głosząc wszędzie nauki. Wielką wagę przywiązywał do katechizacji dzieci i młodzieży ${ }^{27}$. Wstępował również na modlitwę do cerkwi greckokatolickich i składał wizyty duchownym tegoż obrządku ${ }^{28}$. W 1907 roku wizytował także parafie węgierskie na Bukowinie ${ }^{29}$.

Praktykę regularnego wizytowania parafii kontynuował abp Bolesław Twardowski (1924-1944) ${ }^{30}$, którego w tych czynnościach wspierał biskup pomocniczy Eugeniusz Baziak (1933-1944; 1944-1962 arcybiskup-metropolita lwowski) ${ }^{31}$. Szczegółowe zasady dotyczące ich przygotowania i przebiegu podawała „Instrukcja dla Wiel. Ks. Dziekanów i Proboszczów lwowskiej archidiecezji obrz. łac. o wi-

${ }^{21}$ Tamże.

${ }^{22}$ K. R. Prokop, Arcybiskupi haliccy i lwowscy. Szkice biograficzne. Biały Dunajec-Ostróg 2010, s. 288, 290, 306.

${ }^{23}$ Currenda, N. 1498, Lwów, 1 VII 1858 [Odezwa Andrzeja Ostrawskiego, prepozyta Kapituły w sprawie śmierci abp. Ł. Baranieckiego, druk Ossolineum, s. 1]; Prokop, Arcybiskupi haliccy, s. 317-319.

${ }^{24}$ B. Kumor, Ustrój i organizacja Kościoła polskiego w okresie niewoli narodowej (1772-1918), Kraków 1980, s. 631.

${ }^{25}$ E. Wójcik, Działalność duszpasterska arcybiskupa Seweryna Morawskiego w archidiecezji lwowskiej obrządku łacińskiego w latach 1884-1900 na podstawie źródeł drukowanych, Lublin 1986, s. 56 (mps w zbiorach autora); B. Kumor, Morawski Seweryn Tytus (1819-1900), w: Polski Słownik Biograficzny, t. 21, Wrocław1976, s. 743.

${ }^{26}$ Wójcik, Działalność duszpasterska arcybiskupa Seweryna Morawskiego, s. 54-55.

${ }^{27}$ M. Tarnawski, Arcybiskup Józef Bilczewski. Krótki rys życia i prac, Lwów 1924, s. 55-56.

${ }^{28}$ Tamże, s. 57-58.

${ }^{29}$ Tamże, s. 60-61.

${ }^{30}$ G. Chajko, Arcybiskup Bolesław Twardowski (1864-1944). Metropolita lwowski obrządku tacińskiego, Rzeszów 2010; Prokop, Arcybiskupi haliccy, s. 360-374.

${ }^{31}$ „Kurenda Kurii Metropolitalnej obrządku łacińskiego we Lwowie”, Lwów 1924-1939, passim; M. Leszczyński, Arcybiskup Metropolita Eugeniusz Baziak (1890-1962). Życie i działalność duszpasterska, „Currenda”, Tarnów 1988, nr 7-9, s. 348-362. 
zytacji kanonicznej", wydana przez abp. Twardowskiego w 1938 roku ${ }^{32}$. W myśl jej postanowień, w pierwszym dniu wizytacji, w godzinach rannych, odbywała się spowiedź wiernych, po czym biskup celebrował ,cichą” Mszę św., w czasie której wierni śpiewali Godzinki do Najśw. Maryi Panny. Po Komunii św. odbywało się bierzmowanie, następnie jeden z kapłanów dekanalnych celebrował sumę (z wystawieniem Najśw. Sakramentu w monstrancji), a kazanie wygłaszał miejscowy proboszcz. Po Mszy św. miała miejsce procesja z okolicznościowym przemówieniem biskupa oraz spotkanie z przedstawicielami wiernych i stowarzyszeń kościelnych $^{33}$. W tym też dniu odbywała się konsekracja kościoła, jeśli taka była przewidziana ${ }^{34}$. Gdy wizytację kontynuowano w drugim dniu, to wtedy odbywała się katechizacja dzieci szkolnych ${ }^{35}$. Podczas wizytacji biskupowi towarzyszył miejscowy dziekan ${ }^{36}$. W związku z tym wydarzeniem kapłani dekanalni mieli uwzględnić we Mszy św. kolektę ,pro peregrinantibus”, zgodnie z aktualnym kalendarzem liturgicznym ${ }^{37}$.

Zapowiedzi ostatnich wizytacji kanonicznych przed wybuchem II wojny światowej ogłoszono w Kurendzie Kurii Metropolitalnej z 15 kwietnia 1939 roku. I tak abp Twardowski miał wizytować w maju tr. dek. Lubaczów, zaś abp Baziak dek. Żółkiew i Buczacz, a w jesieni Trembowlę i Busk ${ }^{38}$.

\section{Wizytacje dziekańskie}

Obowiązek wizytowania parafii przez dziekanów w archidiecezji lwowskiej istniał już przed 1597 roku, a ich kompetencje w tym zakresie sprecyzował synod, zwołany przez abp. Grochowskiego w 1641 roku. W myśl jego uchwał dziekani mieli wizytować wszystkich duchownych i świeckich zatrudnionych w parafiach, w tym także nauczycieli, zakrystianów i „dzwonników" ${ }^{39}$. Oto fragment tych postanowień: „Dziekani winni przynajmniej dwa razy do roku wizytować jak najdokładniej swój dziekanat: na niedbałych w tym względzie spadną stosowne kary. Jeżeli w czasie tej wizytacji natrafią na jaką większą trudność, mają zasięgnąć rady wybitnych kapłanów swego okręgu, a następnie zarządzić, co po tej wspólnej naradzie uznają za najlepsze. Gdyby zaś wypadek był tak zawikłany, żeby sobie rady dać nie mogli, powinni udać się po radę i pomoc do władzy diecezjalnej. Kto

${ }^{32}$ Instrukcja dla Wiel. Ks. Dziekanów i Proboszczów lwowskiej archidiecezji obrz. łac. o wizytacji kanonicznej, Lwów 1938, ss. 21.

${ }^{33}$ Tamże, s. 13-19 §21-30.

${ }^{34}$ Tamże, s. 20 §35.

${ }^{35}$ Tamże, s. $19 \S 31$.

${ }^{36}$ Tamże, s. $36 \S 36$.

37 „Kurenda”, Lwów 15 IV 1939, nr 8, s. 1.

38 „Kurenda”, Lwów, 15 III 1939, nr 6, s. 1.

${ }^{39}$ Krętosz, Organizacja archidiecezji, s. 174-175. 
by wezwany przez dziekana na taką naradę wzdragał się przybyć, podpada karze pieniężnej. Pieniądze te przypadają w udziale szpitalowi kapłanów"40.

O wizytowaniu parafii przypominali dziekanom m.in. arcybiskupi: Zieliński, Skarbek i Sierakowski ${ }^{41}$. Dziekani mieli sprawdzać stan ksiąg liturgicznych i kancelaryjnych oraz porządek w kościele, a także dopilnować, by dekrety wydane przez biskupów w czasie wizytacji pasterskich były wprowadzone przez duchowieństwo w życie ${ }^{42}$. Ten ich obowiązek potwierdził synod lwowski w 1765 roku, zwołany przez abp. Sierakowskiego. W 1783 roku władze austriackie narzuciły dziekanowi wizytującemu parafię urzędnika państwowego, ale to zarządzenie cesarz Franciszek II zawiesił w 1801 roku. Polecał im jednak wizytować parafię każdego roku, zwracając szczególną uwagę na budynki kościelne i dobra klasztorne ${ }^{43}$.

Dziekani wizytowali parafie według kwestionariusza, zatwierdzonego przez biskupa ordynariusza. I tak np. pytania z kwestionariusza wizytacyjnego dek. Rohatyn z 1783 roku dotyczyły takich kwestii, jak: życie i uprawnienia kapłanów do sprawowania czynności duszpasterskich, stan zakonów i szkół, konsekracja i poświęcenie kościoła, przywileje dla głównego ołtarza, stan ołtarzy, chrzcielnicy, olejów świętych, paramentów liturgicznych, ksiąg metrykalnych, inwentarza kościoła i księgi wpisów, a także ogłaszanie z ambony rozporządzeń biskupa i władz państwowych. Z kolei dziekan wizytujący dek. Brzeżany w 1802 roku pytał proboszczów także o takie kwestie, jak: ich obowiązki wynikające $z$ dokumentu fundacyjnego parafii, zaświadczenie ukończenia przez księży kursu z katechetyki, sprawy kaznodziejskie, dokładny plan służby Bożej w kościele, sprawowanie sakramentów św. i dobroczynność w parafii ${ }^{44}$.

Praktyka regularnych wizytacji dziekańskich powróciła na początku XIX w. ${ }^{45}$ Szczegółowe instrukcje w tym względzie wydali m.in. arcybiskupi: Ł. Baranie$\mathrm{cki}^{46}$ i S. Morawski. W myśl instrukcji abp. Morawskiego dziekan miał rozpoczynać wizytację parafii od modlitwy przed Najśw. Sakramentem, a następnie lustrować kościół parafialny i jego otoczenie, cmentarze, kaplice, szkoły i kancelarię parafialną. Był też zobowiązany przeprowadzić rozmowę z proboszczem na temat życia sakramentalnego, służby Bożej, nauczania, moralności duchowieństwa i wiernych oraz fundacji, budownictwa i majątku kościelnego. Rozmowę miał odbyć także z wikariuszem (wikariuszami) oraz przedstawicielami parafian, nt. sprawowania przez duchownych sakramentów św. i nabożeństw ${ }^{47}$. Z kolei abp Bilczewski przypominał dziekanom, by z przeprowadzonych wizytacji sporzą-

${ }^{40} \mathrm{~S}$. Wysocki, Krótka wiadomość o drukowanych zbiorach ustaw synodalnych prowincji i archidiecezji lwowskiej obrz. łac., Lwów 1908, s. 20.

${ }^{41}$ Krętosz, Organizacja archidiecezji, s. 174-175.

${ }^{42}$ CIC 1917, kan. 447 §1 i 2; F. Bączkowicz, Prawo kanoniczne, t. 1, s. 572.

${ }^{43}$ Krętosz, Archidiecezja lwowska, s. 122.

${ }^{44}$ Tamże, s. 123.

${ }^{45}$ Tamże.

${ }^{46}$ Prokop, Arcybiskupi haliccy, s. 319.

${ }^{47}$ Instructio pro P.T. Decanis intuitu instituendae visitationis decanalis, „Kurenda”, Lwów 1896, nr 31, s. 22-30; Podręcznik urzędów parafialnych wedle Kurend łac. Konsystorza Lwowskiego z lat 1841 do 1897, oprac. K. Loga, Lwów 1899, s. 55-63. 
dzali dokładne sprawozdania, gdyż zawarte w nich informacje będą cennym materiałem do dziejów archidiecezji ${ }^{48}$. Natomiast abp Twardowski zobowiązał proboszczów, by sprawozdania z wizytacji dziekańskich przesyłali biskupowi mającemu wizytować parafię, na 10 tygodni przed jej terminem. Do tegoż sprawozdania mieli dołączyć szkic okręgu parafialnego, mapy gruntów kościelnych, beneficjalnych i fundacyjnych oraz spis dokumentów parafialnych ${ }^{49}$.

\section{Zakończenie}

Prawo kościelne nakładało na rządców archidiecezji obowiązek wizytowania parafii, ale praktyka w tym względzie, w ciągu wieków, była różna. Byli tacy arcybiskupi, jak np. Wacław H. Sierakowski (1760-1780) i Józef Bilczewski (19001923), którzy odbywali je regularnie. Inni zaś, jak np. Seweryn T. Morawski (1885-1900), nie prowadzili ich osobiście, lecz delegowali do tego biskupa pomocniczego, względnie innych kapłanów. Celem wizytacji kanonicznych było poznanie przez władzę kościelną stanu i potrzeb parafii, a także kontrola zakresu wprowadzenia przez duchowieństwo w życie prawa kościelnego (w tym synodalnego) i innych zarządzeń kościelnych.

W ścisłym związku z wizytacjami pasterskimi pozostawały wizytacje prowadzone przez księży dziekanów. Ich sprawozdania zawierały bogate źródło informacji o stanie duchowieństwa i parafii, co ułatwiało rządcom archidiecezji ich wizytowanie. Sprawozdania dziekańskie były szczególnie cenne wtedy, gdy nie odbywały się regularnie wizytacje kanoniczne.

\footnotetext{
48 „Kurenda”, Lwów 1921, nr 11, s. 46.

${ }^{49}$ W sprawie sprawozdań powizytacyjnych, „Kurenda”, Lwów 1928, nr 15, s. 74.
} 


\title{
CANONICAL AND DEANERY VISITATIONS IN THE ARCHDIOCESE OF LVIV OF THE LATIN RITE TO 1939
}

\begin{abstract}
Summary
One of the important duties of the rulers of a diocese was to conduct canonical visitations in parishes (visitatio canonica, visitatio pastoralis). According to the recommendations of the Council of Trent (1545-1563), suffragan bishops (assistant) were supposed to help them in this duty. Detailed standards for the canonical visitations of parishes in the 20thy century were included in the Code of Canon Law of 1917. They said, among other things, that every year the "residential" bishop should visit his diocese or part of it so that to visit at least one parish every five years. He was supposed to perform this task in person or-in case of a reasonable obstacle-by a vicar general, or by another clergyman. Bishops conducted visitation of people, things and pious establishments, apart from the ones which received a special exemption from the Holy See.

The practice of canonical and deanery visitations in the Archdiocese of Lviv of the Latin rite varied over the centuries. Regular visitations were conducted, for example by Archbishop Wacław Hieronim Sierakowski (1760-1780) and Józef Bilczewski (1900-1923). Archbishop Seweryn Tytus Morawski (1885-1900) did not conduct any visitations in person, he would entrust this task to the assistant bishop or other clergymen. Deanery visitations were closely connected with canonical ones; and they were especially important when canonical visitations were not conducted regularly. The aim of deanery and canonical visitations was to recognise the condition and the needs of the parish and to control the implementation of ecclesiastical law and other ordinances of ecclesiastical authorities.
\end{abstract}

